\title{
Investigating important factors influencing on strategic marketing planning
}

\author{
Davood Salmani $^{a^{*}}$, Mohammad Reza Daraei ${ }^{\mathrm{b}}$ and Ali Bayazdi ${ }^{\mathrm{c}}$
}

${ }^{a}$ Associated Professor, Department of Management and Accounting, University of Tehran, Tehran, Iran

${ }^{b}$ Department of management, Payam noor university, PO BOX 19395-3697 Tehran, IR of Iran

${ }^{c}$ Ms student, Payame Noor University, Damavand Branch, Tehran, Iran

\section{H R O N I C L E}

Article history:

Received June 28, 2013

Received in revised format

19 October 2013

Accepted 20 December 2013

Available online

December 272013

\section{Keywords:}

Marketing strategy

Wholesalers

Bargaining pricing

New rivals

\section{A B S T R A C T}

One of the most important methods for building good marketing strategy is to learn more about existing competitors, suppliers, etc. This paper presents an empirical investigation to study the relationship between wholesalers, bargaining pricing, new rivals and pricing strategy on preparing appropriate marketing strategy in meat market in city of shiraz, Iran. The proposed study designs a questionnaire in Likert scale and distributes it among 200 experts in this market. Cronbach alpha has been calculated as $97.3 \%$, which validates the overall survey. The results of the implementation of Pearson correlation ratio indicate that there were some positive and meaningful relationships between all components of the survey with marketing strategy.

(C) 2014 Growing Science Ltd. All rights reserved.

\section{Introduction}

Marketing strategy plays essential role for the success of most organizations in getting more market share and building sustainable growth (Dess \& Miller, 1995; Kotler \& Roberto, 1989; Kotler et al., 2004; Kotler, 2009). According to Day (1981), the strategic planning framework, which builds links between business units and product-market units have to reflect a strategically relevant balance of cost and demand factors. Kotler and Gertner (2002) examined how widely held country images influence attitudes towards a country's products and services and capability to attract investment, businesses and tourists. They evaluated the role of strategic marketing management in promoting the country's image, attractiveness and products. Tamagnini and Tregear (1998) performed an assessment of niche marketing opportunities in the delicatessen meat sector. They presented the findings of a research project, which studied the suitability of the United Kingdom as a possible niche market for a specialty Portuguese smoked sausage (Chouriço de Portalegre). They began with a discussion of 
niche marketing theory, and proposed three criteria, which a potential niche market should adhere to. These criteria are then applied as tools of evaluating the potential of the UK as a niche market, using some secondary and primary research. They reported that the Chouriço de Portalegre had an appropriate mix of qualities for niche marketing in the UK, but that issues of intermediary and customer knowledge and communication of product advantages need to be overcome. Ahmed (2008) explored a number of marketing issues, such as consumer buyer behavior and distribution channels, in association with buying halal meat (HM) from local shops versus supermarkets in the United Kingdom. They reported that the majority of UK Muslims had not trust big supermarkets when purchasing HM and they only trusted a Muslim selling halal products in their local shops. McEachern and Warnaby (2005) discussed how to improve customer orientation within the fresh meat supply chain by concentrating on assurance schemes. They concluded that producer-led logos were the preferred assurance labels to be bought by consumers and that the most significant impacts upon buying behavior were attitudes, past behavior, assurance label knowledge and personal identity traits. In addition, weaknesses were detected in terms of producer-led groups' marketing communication strategies to consumers.

\section{The proposed study}

This paper presents an empirical investigation to study the relationship between wholesalers, bargaining pricing, new rivals and pricing strategy on preparing appropriate marketing strategy in meat market in city of Shiraz, Iran. The proposed study of this paper considers the following hypotheses,

1. There is a meaningful relationship between accessing wholesalers and reaching better market share.

2. There is a meaningful relationship between suppliers' bargaining power and reaching better market share.

3. There is a meaningful relationship between new rivals and reaching better market share.

4. There is a meaningful relationship between pricing strategy and reaching better market share.

The proposed study has been applied among some experts in food suppliers and the survey has designed a questionnaire in Likert scale and distributed it among 200 randomly selected people. Cronbach alpha has been calculated as $97.3 \%$, which is well above the desirable level of 0.7 .

\subsection{Personal characteristics of the participants}

In our survey, approximately $90 \%$ of the participants were male and the remaining $10 \%$ were female. Fig. 1 demonstrates other personal characteristics of the participants.

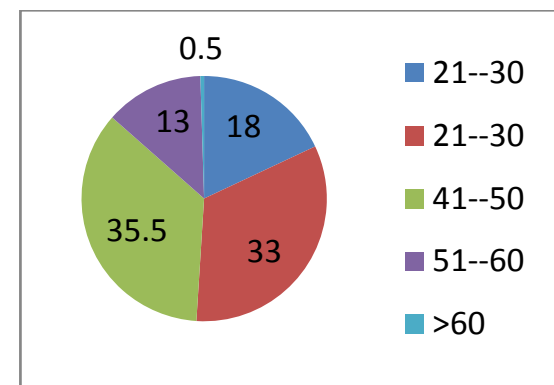

Age

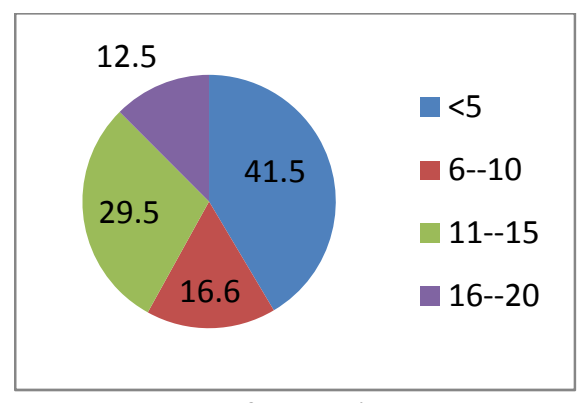

Years of experiences

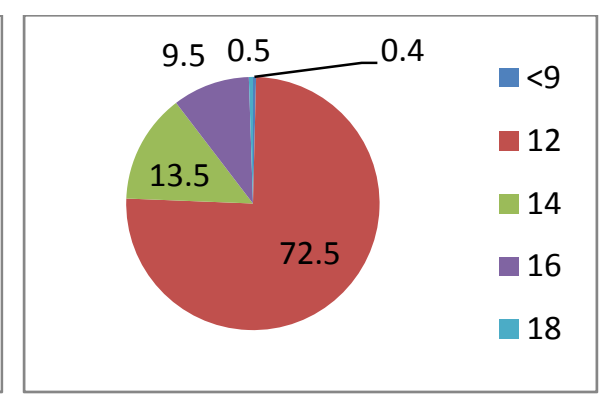

Educational background

Fig. 1. Personal characteristics of the participants 
As we can observe from Fig. 1, most participants are middle age, with some job experiences and educational background. The proposed study designs a questionnaire in Likert scale and distributes it among 200 experts in this market. Cronbach alpha has been calculated as $97.3 \%$, which validates the overall survey. Next, we have realized that all data were normally distributed through the implementation of Kolmogorov-Smirnov. Therefore, the proposed study uses Pearson correlation test to verify different hypotheses of the survey.

\section{The results}

In this section, we present details of our findings on testing various hypotheses of the survey. Table 1 demonstrates the results of our survey.

\section{Table 1}

The results of Pearson correlation

\begin{tabular}{llll}
\hline Hypothesis & r & Sig. & Result \\
\hline 1. The relationship between wholesalers and marking strategy & 0.918 & 0.000 & Confirmed \\
\hline 2. The relationship between suppliers' bargaining power and marking strategy & 0.868 & 0.000 & Confirmed \\
3. The relationship between new rivals and marking strategy & 0.916 & 0.000 & Confirmed \\
4. The relationship between pricing strategy and marking strategy & 0.876 & 0.000 & Confirmed \\
\hline
\end{tabular}

As we can observe from the results of Table 1, there are some positive and meaningful relationships between wholesalers, suppliers' bargaining power, new rivals as well as pricing strategy and marketing strategy. Therefore, the implementation of Pearson correlation confirms four hypotheses of the survey. We have also performed stepwise regression analysis and Table 2 shows details of our findings.

\section{Table 2}

The summary of stepwise regression analysis

\begin{tabular}{lccc}
\hline Variable & Non-standard $\beta$ & Standard $\beta$ & Sig. \\
\hline Wholesalers & 1.067 & 0.918 & 0.000 \\
Bargaining power & 0.993 & 0.868 & 0.000 \\
New rivals & 1.034 & 0.916 & 0.000 \\
Pricing strategy & 0.947 & 0.876 & 0.000 \\
\hline
\end{tabular}

Based on the results of Table 2, there are positive and meaningful relationships between pricing strategy as dependent variable and four independent variables including wholesalers, bargaining power, new rivals and pricing strategy.

\section{Conclusion}

One of the most important issues in marketing strategy is to select appropriate business actions to deal with competitors not only to keep the existing market share but also to penetrate into market and absorb new market share. In this paper, we have investigated the effects of four factors, namely wholesalers, bargaining power, new rivals and pricing strategy on marketing planning. The implementation of Pearson correlation ratio as well as stepwise regression technique has revealed that these components could positively influence on marketing strategy.

\section{Acknowledgement}

The authors would like to thank the anonymous referees for constructive comments on earlier version of this paper. 


\section{References}

Ahmed, A. (2008). Marketing of halal meat in the United Kingdom: Supermarkets versus local shops. British Food Journal, 110(7), 655-670.

Day, G. S. (1981). Strategic market analysis and definition: an integrated approach. Strategic Management Journal, 2(3), 281-299.

Dess, G. G., \& Miller, A. (1995). Strategic Management. McGraw-Hill.

Kotler, P., \& Roberto, E. L. (1989). Social marketing: Strategies for changing public behavior (p. 25). New York: Free Press.

Kotler, P., \& Gertner, D. (2002). Country as brand, product, and beyond: A place marketing and brand management perspective. The Journal of Brand Management, 9(4), 249-261.

Kotler, P., Brown, L., Adam, S., Burton, S., \& Armstrong, G. (2004). Marketing. Pearsons Education Australia.

Kotler, P. (2009). Marketing management. Pearson Education India.

McEachern, M., \& Warnaby, G. G. (2005). Improving customer orientation within the fresh meat supply chain: a focus on assurance schemes. Journal of Marketing Management, 21(1-2), 89-115.

Tamagnini, V., \& Tregear, A. (1998). An assessment of niche marketing opportunities in the delicatessen meat sector. British food journal, 100(5), 228-235. 